\title{
Disseminated Fusarium Infections in Acute Lymphoblastic Leukemia
}

\author{
Morgan COVINGTON¹, Juliana GAO², Farah ABDULLA, Vesna PETRONIĆ ROSIĆ2 \\ ${ }^{1}$ Pritzker School of Medicine, The University of Chicago, Chicago, IL, USA \\ ${ }^{2}$ Section of Dermatology, Department of Medicine, The University of Chicago, Chicago, IL, USA \\ ${ }^{3}$ Division of Dermatology, City of Hope, Duarte, CA, USA \\ *Correspondence: Vesna Petronić Rosić, E-mail: vprosic@uchicago.edu \\ UDC 616.992:616.155.392
}

\begin{abstract}
Fusarium is a ubiquitous fungal species found in soil and water. While fusarium can cause localized infection in healthy individuals, it most commonly affects those with compromised immune systems, particularly those with prolonged neutropenia. The morality rate of systemic infection approaches one-hundred percent. Here we present two cases of disseminated fusarium infection in two patients with acute lymphoblastic leukemia (ALL) along with review of literatures regarding prophylaxis and treatment.
\end{abstract}

Key words: Precursor Cell Lymphoblastic Leukemia-Lymphoma; Fusariosis; Case Reports; Immunocompromised Host

\section{Case Report}

Patient A was a 45-year-old Caucasian woman with a history of ALL, 182 days status post stem cell transplant, complicated by graft vs. host disease (GVHD) and two relapses of her ALL who presented as an urgent consult to dermatology clinic for a one-week history of rash. Her chemotherapy regimen included an experimental selective tyrosine kinase inhibitor, vincristine, intra-thecal cytarabine, and dexamethasone. Antimicrobial prophylaxis included levofloxacin, acyclovir, and posaconazole. On exam, she had multi- ple erythematous to purpuric slightly indurated papules and plaques scattered on her face, arms, and legs, along with several tender papules and nodules with occasional dusky centers on the lower legs (Figure 1).

Patient B was also a 45-year-old Caucasian woman with a history of ALL, 225 days status post stem cell transplant, and previous breast cancer who developed a rash two days after being admitted for headache and syncope. Her chemotherapy regimen included a SYK inhibitor and ruxolitinib. Her antimicrobial prophylaxis regimen consisted of acyclo-
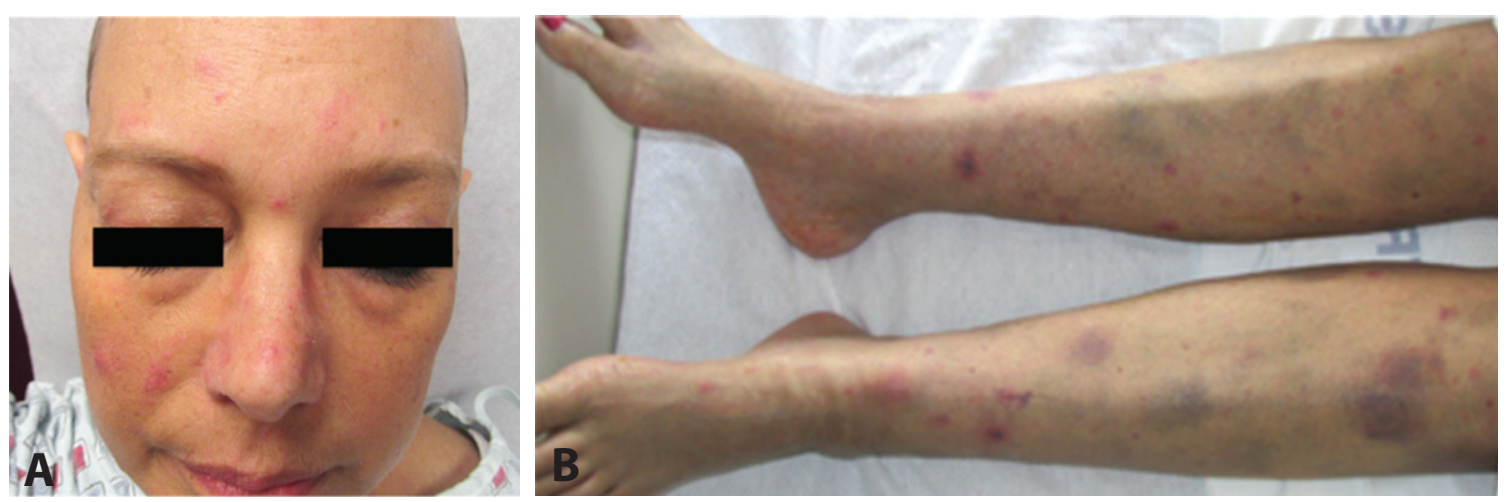

Figure 1. Multiple erythematous to purpuric papules and plaques scattered on her face $(A)$, and legs in Patient $A(B)$ 


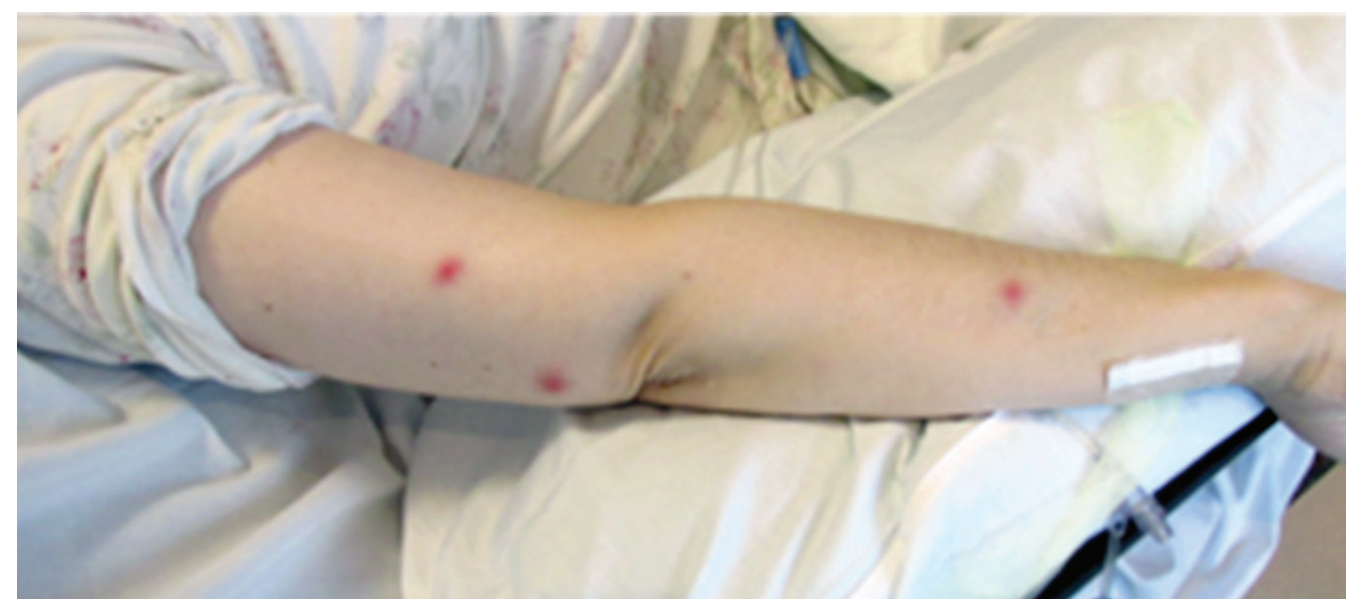

Figure 2. Firm, red, and indurated lesions on her right upper arm in patient B

vir and micafungin. On exam, there were firm, tender, red, and indurated lesions on her right upper arm, anterior neck, and the dorsum of the right foot (Figure 2).

Punch biopsies of the skin and blood cultures were taken from both patients. Hematoxylin-and-eosin, Periodic acid-Schiff (PAS) and Gomori methenamine silver (GMS) stains performed on the skin biopsies showed hyphal elements (Figures 3 and 4) within the blood vessels walls and lumens in both cases. Blood cultures later grew Fusarium, confirming the diagnosis of disseminated Fusarium infection in both patients.

Both patients received the standard treatment consisting of IV amphotericin B. Invasive fungal sinusitis was also confirmed in both women via endoscopic debridement of nasopharyngeal mucosa by otolaryngology. Chemotherapy was discontinued in patient $A$, and Patient B was given G-CSF. Unfortunately, neither patient improved with treatment. Patient $A$ discontinued antifungal treatment and was discharged to home hospice care where she later passed away. Patient B was transferred to the intensive care unit where she eventually succumbed to infection and multiorgan failure.

\section{Discussion}

The ubiquitous mold Fusarium enters the body via inhalation into the upper airways and lungs as well as through breaks in the skin
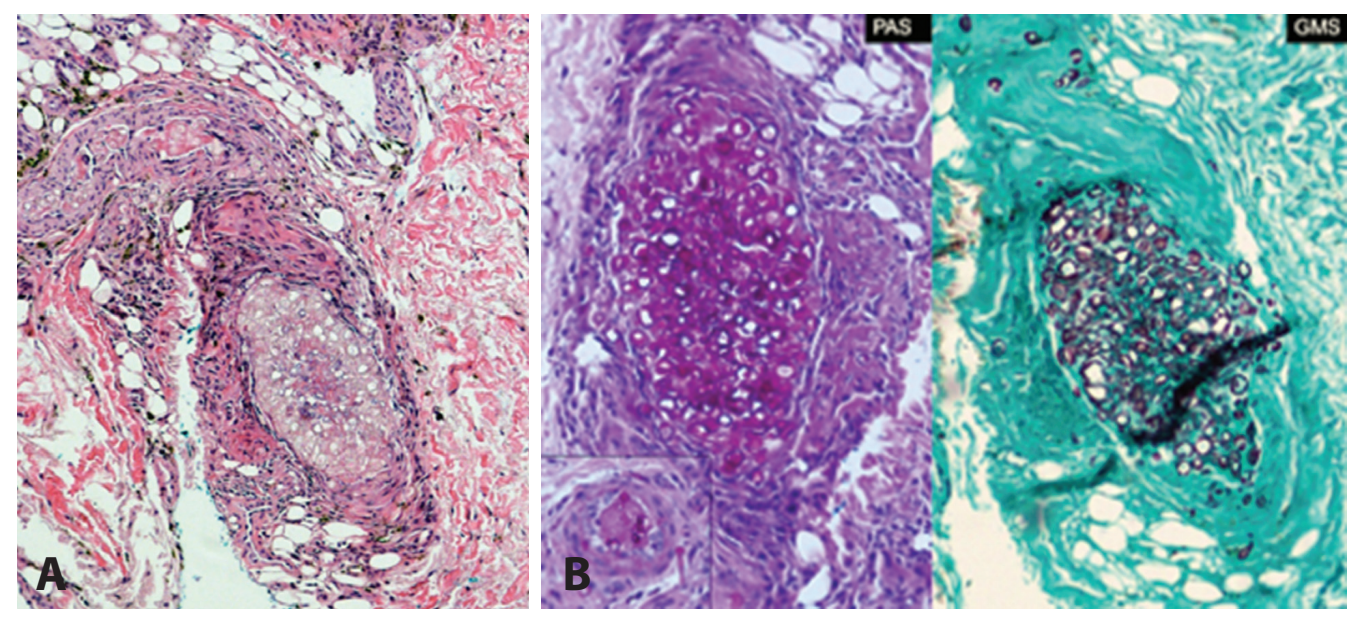

Figure 3. Biopsy from patient A. Cross-sections of numerous hyphal elements occluding blood vessel lumina (A). These fungal elements were also positive on Periodic acid-Schiff (PAS) and Grocott's methenamine silver (GMS) stains (B). 

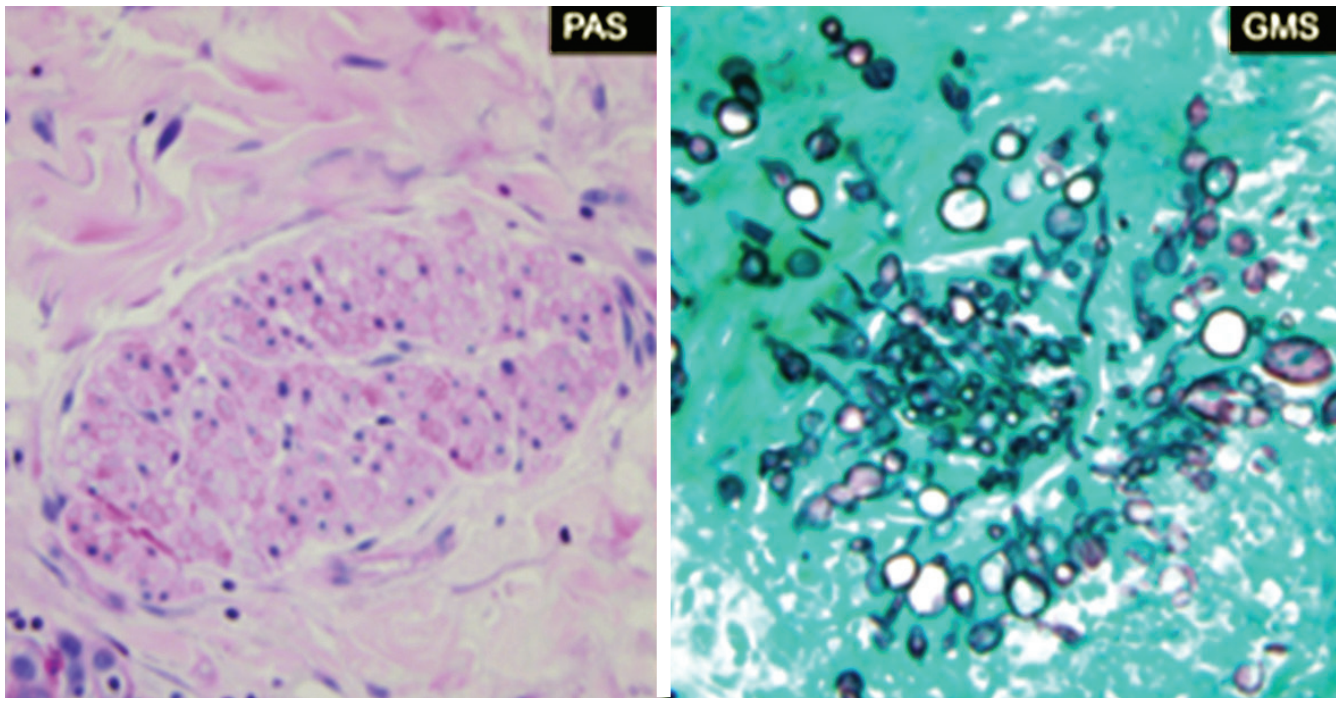

Figure 4. Biopsy from patient B. Septate hyphal elements seen on PAS and GMS stains

and mucous membranes (1-4). In humans, Fusarium causes a range of superficial, locally invasive, and systemic disease states that are closely related to the host's immune status. In those with intact immune systems, fusarial keratitis and onychomycosis are the most common infections (3). Risk factors for disseminated infections include neutropenia, lymphopenia, graft versus host disease, and prolonged corticosteroid therapy (5). Immunocompromised patients are at risk for systemic infection such as invasive sinusitis, pneumonia and fungemia (3).

Fusarium is notable for its relative resistance to most antifungal agents available. Currently, the most common treatments for fusariosis are limited to voriconazole, posaconazole, and amphotericin B. At the moment, there is no solid evidence to support the use of combination therapy. In patients with compromised immune system, it has been suggested that the decreasing immunosuppression should be considered in the setting of infection in order to maintain and stimulate body's own immune defenses (6). This can be achieved by decreasing or stopping the respective chemotherapy, using granulocyte stimulating factors, and/or granulocyte transfusions.

While the mortality rate in disseminated Fusarium infections is extremely high, the delay of diagnosis and initiation of treatment may also have an impact on survivorship. Unfortunately, presenting symptoms including the skin findings are often nonspecific; blood and tissue culture may also take hours to days. Furthermore, standard antimicrobial prophylaxis such as micafungin or itraconazole does not provide adequate coverage for Fusarium. The preferred antifungal prophylaxis against invasive molds such as Fusarium and Aspergillus is posaconazole; however, even that may not be sufficient for patients with persistent neutropenia (7). Until better prophylactic management in immunosuppressed patients can be achieved, a high index of suspicion along with prompt diagnosis and treatment are paramount for the treatment of disseminated Fusarium infection.

\section{Abbreviation}

ALL - acute lymphoblastic leukemia

PAS - periodic-acid Schiff

GMS - Gomori methenamine silver

SYK - spleen tyrosine kinase

\section{References:}

1. Nelson PE, Dignani MC, Anaissie EJ. Taxonomy, biology, and clinical aspects of Fusarium species. Clin Microbiol Rev. 1994;7(4):479-504.

2. Galimberti R, Torre AC, Baztán MC, Rodriguez-Chiappetta F. Emerging systemic fungal infections. Clin Dermatol. 2012;30(6):633-50.

3. Nucci M, Anaissie E. Fusarium infections in immunocompromised patients. Clin Microbiol Rev. 2007;20(4):695-704. 
4. Fridkin SK, Jarvis WR. Epidemiology of nosocomial fungal infections. Clin Microbiol Rev. 1996;9(4):499-511.

5. Dignani MC, Anaissie E. Human fusariosis. Clin Microbiol Infect. 2004;10 Suppl 1:67-75.

6. Nucci F, Nouér SA, Capone D, Anaissie E, Nucci M. Fusariosis. Semin Respir Crit Care Med. 2015; 36(5):706-14.
7. Freifeld AG, Bow EJ, Sepkowitz KA, Boeckh MJ, Ito $\mathrm{JI}$, Mullen CA, et al. Clinical practice guideline for the use of antimicrobial agents in neutropenic patients with cancer: 2010 update by the Infectious Diseases Society of America. Clin Infect Dis. 2011;52(4):e56-93.

\section{Diseminovane Fusarium infekcije kod akutne limfoblastne leukemije}

\section{Sažetak}

Fusarium je sveprisutna vrsta gljivica koja se može naći u tlu i vodi. I dok Fusarium može izazvati lokalizovanu infekciju kod zdravih osoba, ipak najčešće napada osobe sa kompromitovanim imunosistemom, pogotovo one sa produženom neutropenijom. Stopa smrtnosti od sis- temske infekcije je blizu sto posto. Ovde su prikazana dva slučaja diseminovane Fusarium infekcije kod dva pacijenta sa akutnom limfoblastnom leukemijom zajedno sa pregledom literature koja se odnosi na profilaksu i lečenje.

Ključne reči: Akutna limfoblastna leukemija; Fusarioza; Prikazi slučajeva; Imunokompromitovani bolesnici

Received 27 March, 2018

Accepted 8 April, 2018 